\title{
低温ケーブルと断熱・電気絶縁
}

\author{
隈 彰 二・深 沢 正 名 \\ 日立電線(株)研究所 茨城県日立市日高町 5 の 1 \\ (1974年 3 月 7 日受理)
}

\section{Thermal and Electrical Insulations for Cryogenic Cables}

\author{
Shoji Kuma and Masana Fukasawa \\ Research Lab. Hitachi Cable, Ltd. 5-1, Hitaka-machi, Hitachi-shi
}

(Received March 7, 1974)

\section{Synopsis :}

This article introduces the cryogenic power cable, especially its thermal and electrical insulations. These are important matters on the reliability of cryogenic cables. Thermal insulating methods for cables are similar to general cryogenic vesseles. However the length of the cable makes some troubles in evacuation, formation, etc. The applications of thermal insulating methods are discussed with the examples of several plants. Electrical insulating materials at low temperature have been researched in these few years. Solid materials have no reliability because of thermal cracks. Polyethylene paper laminated insulation impregnated with liquid nitrogen has good performance for liquid nitrogen cooled cable. For the superconductive cable, supercritical helium impregnated tape-type insulator seems promissing as electrical insulating methods.

\section{1. まえがき}

超電導現象の発見以来, 超電導送電は夢の送電線路 として多くの人々の話題にのぼってきた。1960年代に なり, 超電導マグネットの成功に刺激され, また, 超 電導線材の工業規模の製造, 低温技術の向上などの技 術的進歩にともない, 現実的な話題として超電導送電 の可能性が検討されるようになった。1962年, 超電導 ケーブルの具体的構想が R. McFee により初めて発 表された1)。彼は 3 種類の超電導ケーブルを提案し, 当時の米国における全電力需要を腕一本の太さのケー ブルで送電できると述べている。その後, 数多くの超 電導送電に関する提案, 概念設計, 経済試算などが試 みられ22 4)，1969年英国 CERL の $2 \mathrm{~m}$ モデル線路が つくられ5)，モデル線路による実験検討の時代に入っ た。

一方，低温に扮ける導体抵抗の減少を利用し低温冷
媒による強制冷却をおこなら抵抗性低温ケーブル (Cryoresistive Cable) の検討もおこなわれ, 超電導 ケーブルとの経済比較がなされた ${ }^{6)}$ 。結論的には超電 導ケーブルの優位注明らかであるが，液体へリウム温 度に扔ける各種材料の工学的データの不足など技術的 未解決の問題が多く, 現在の電力事情からの要請に答 えるためには液体窒素冷却抵抗性低温ケーブルは十分 魅力的である。

我国に捛いては1962年頃から各電線メーカは超電導 ケーブルの調査, 概念設計を始め, 1963年電力中研送 電機能研究会は超電導送電の概念設計, 試算をおこな っている7)。電力中研は翌年から超電導送電㦝談会を 発足させ, 1968 年にはこれを超電導送電委員会と改 称, メ一カも参加して概念設計, 問題点の明確化など をおこない, 日本の超電導送電研究の原動力となっ $た^{8)}$ 。また, 電総研も超電導送電の基礎的研究から出 発し, 開発研究に着手している9)。一方, 大容量送電

Vol. 9 No. 4 (1974) 
ケーブル開発の一環として各電線メーカ流液体空素冷 却抵抗性ケーブルの試作に着手し，モデル線路による 各種試験をおこなつている ${ }^{10) ~ 12) 。 ~}$

低温ケーブルの開発に際して未だ数多くの問題が残 されているがここではその信頼性に関係する断熱上 電気絶縁について述べる。

\section{2. 電カケーブル}

低温ケーブルについて述べる前に，従来の代表的な 電力ケーブルである OF ケーブル (Oil Filled Cable) 在説明しておく。図 1 に $500 \mathrm{kV}$ OF ケーブルの断面 写真をしめす。電力ケーブルは基本的には導体とそれ を取まく絶緣体，さらに絶縁体にかかる電位を均一に 同心円とするための絶縁遮蔽層加らなっている。OF ケーブルの電気絶縁は低粘度油を含浸したクラフト紙 で構成されており，温度変化にともなう油の膨㖘収縮 をケーブル端部の王力槽で吸収するために導体内部に 油通路が設けられている。導体は交流通電による表皮 效果を減少させるために分割され，分割部分はそれぞ れ絶縁されている。この中空導体を絶縁する際，撚線 による電界集中と熱変化による導体, 絶縁体間の空隙 が電気絶緑上問題となるので, カーボン紙による半導

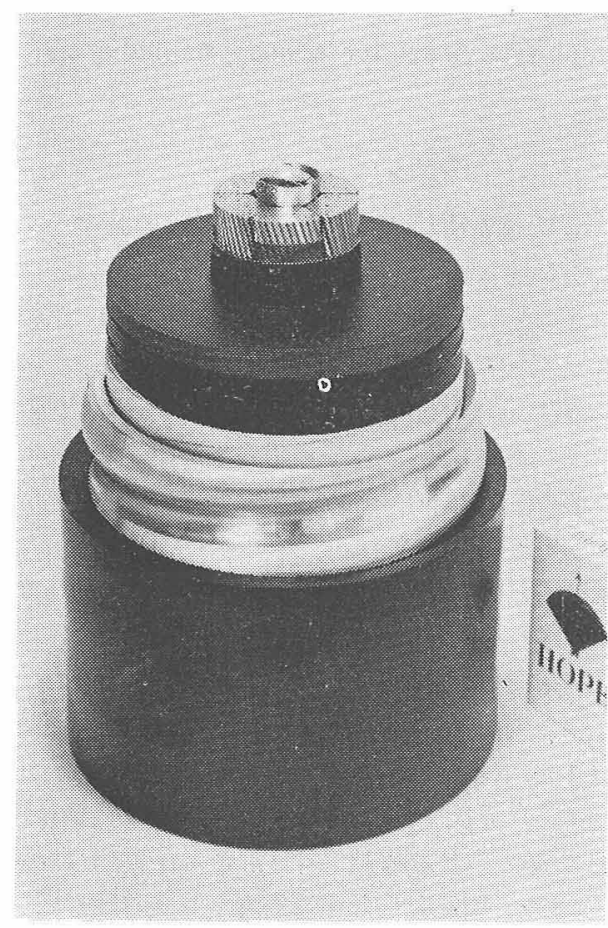

図 $1500 \mathrm{kV} \mathrm{OF}$ ケーブル断面図
電性導体遮蔽層を設けその上にクラフト紙を卷く。ク ーブルをフレキシブルにするため，15〜 40 mm 幅の クラフト紙を $1 \mathrm{~mm}$ 程度のギャップ亮あけ横巻きにす る。絶縁体の外側はやはり半導電層を介して絶縁遮蔽 層が卷かれる。これを $\mathrm{A} 1$ 波付管で被覆し 3 気圧程度 の油圧定かける。

ケーブルの電流容量は, 各材料の熱劣化からきまる 最高使用温度と尊体発熱, 誘電体発熱, シース誘導発 熱からきまる。誘電体発熱は電圧の 2 乘に比例するの で, 絶縁材料としては而電圧の他に誘電正接 $(\tan ð)$

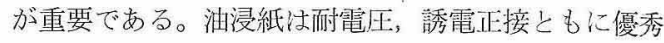
であり，50年以上の実績があり信頼性に富んでいる。

\section{3. 低温ケーブル}

低温ケーブルは原理的には従来型方ーブルを低温に すればよく, 超電導ケーブルでは導体走超電導体に㧍 きかえ机ばよい。しかし，このとき二つの闆題が生じ る。一つは材料の物性変化であり, とくに電気絶縁材 料に㧍いて著しく, 従来の油浸紙は油の固化, クラッ クなどのため使用に耐えない。もう一つの問題法冷却 断熱である。これは低温にするために必要なものであ るが，長尺という点で多くの困嚾がある。この他にも 超電導体の構成など付随した多くの問題がでてくる。

以下，いくつかの低温ヶーブル試騟線路在例にその 構造について述べる。

3.1 リジッド型迢電導ケーブル

リジッド型クーブルばケーブルコアも断熱管路もリ ジッドな構造をもち，8～20m 定尺のものを工場生産 し現地接続するものである。リジッド型迢電導ケーブ ルは英国 $\mathrm{CERL}^{5)}$ ，米国 UCC ${ }^{12}$ 社などで検討されて いる。図 2 にCERL の $2.7 \mathrm{~m}$ 試作線路の断面をしめ す。CERL は通電試験を目的としたので絶縁を考慮し てい察い。ケーブルは単相交流, 厚さ $0.1 \mathrm{~mm} の \mathrm{Nb}$ 管導体をつかった $35 \mathrm{~mm}$ と $55 \mathrm{~mm}$ の同軸構造であ る。

リジッド型超電導ケーブルは超電導中空導体の製造 が比較的容易なため初期の設計に多い。リジッド型年 一ブルの中空導体は $\mathrm{Cu}$ 管または $\mathrm{Al}$ 管上に超電導体 をコートしたもの(交流用)，または埋めこんだもの (直流用) が一般的である。リジッド管であるから耐 压，断熱の設計で有利ではあるが，現地における多層 同軸管の接続，信頼性に問題がある。

3.2 七ミフレキシブル型造電導ケーブル

この型はリジッド型の断熱管路に長尺フレキシブル 


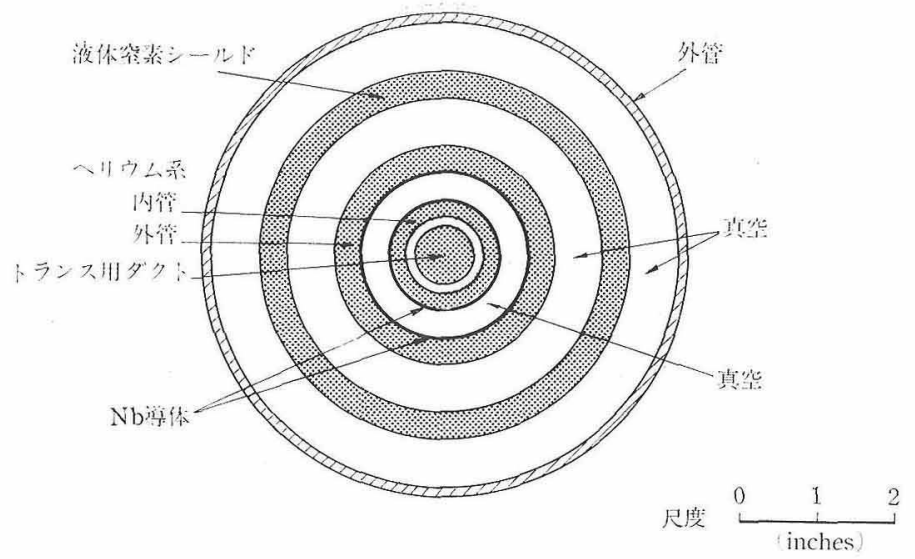

図 2 CERL の試作超電導ヶーブル断面図 のケーブルコア在引込むものであり, 独国 Siemens 社 $^{1+)}$ ，仏国 CGE 社 ${ }^{15)}$ などで検討されている。ケー ブルコアをフレキシブルにするために撚線導体，テー プ巻き積層絶縁構造をとるのが一般的である。交流用 超電導撚線導体は $\mathrm{Cu}$ 線と超電導素線を一緒侁然込 んだものと，Cu 素線上に超電導体をコートし撚線と したものがあり，中空導体としている。直流用撚線素 線は一般のマグネット用線材之同様である。本構造は 断熱管路はリジッド型の長所老残し，導体などの接続 に対する不信を取り除いている。

3.3 フレキシブル型超電導ケーブル

フレキシブル型ケーブルはケーブルコア，断熱管路 ともにフレキシブルなものを呼び, 工皆で一体生産さ れる。この型は独国 $\mathrm{AEG}$ 社で研究されている ${ }^{16)}$ 。そ の構造を図 3 にしめす。導体㤬 $\mathrm{Nb}_{3} \mathrm{Sn}$ を $\mathrm{Cu}$ ストリ ップに蠟付けしたものであり, 絶縁は超臨界 $\mathrm{He}$ 含浸 紙絶縁である。フレキシブル型ケーブルは外径を押え られてしまうので, 尊体表面磁界の点から直流送電用 が有利である。本構造は工場で長尺生産されるので信 頼性に富み, コストも低くなると考えられる。しかし， 断熟などの面から長尺真空排気など問題点も多い。

3.4 リジッド型抵抗性ケーブル

抵抗性低温ケーブルの中で液体窒溸冷却交流ケーブ ルはかなり現実的な研究対象とされている。リジッド 型液体空素泠却ケーブルは図 4 にしめす高真空電気絶 縁, 高真空断熱のものが米国 UGC 社で武作されてい る(7)。スペー步性パイレックス・ガラス老用い，イオ ンシールドとしてチタンリングを入れている。本構造 は長尺真空保持, 導体接続部の遮蔽など問題も多いが, 構造が簡単でありコストも低くなるので鬽力ある構造 である。
3.5 七ミフレキシブル型抵扰性 ケーブル

セミフレキシブル型抵抗性ケーブ ルとしては，20K付近で運転される ヘリウムガス冷却直流々ーブルと 80 $\mathrm{K}$ 付近で運転される液体窒素冷却交 流ケーブルが検討されている102〜12) 19。図 5, 図6 汒日立電線の陚験線 路の断面および試験状況である。目 立電線では液体窒素を循環しながら 課電, 通電党同時におこなう総合的 な試験を第 1 目標として, $66 \mathrm{kV}$, 亘長 $30 \mathrm{~m}$ の試験線路在建設した。 導体は $A 1$ 撚線中空導体 $\left(100 \mathrm{~mm}^{2}\right)$, 電気絶縁液体 窒素含浸ポリエチレン合成紙であり，断熱には発泡ポ リウレタンを用いている。椧却系統は図 7 にしめすよ うに加圧され沸点以下に泠却された液体窒素が循環す る構造である。液体窒菜泠却ケーブル後述するよう に液体空素含浸テープ巻き積層絶縁の特性が優れてい るので，セミフレキシブル型が便利で主流といえる。 また，導体抵抗が減少するとはいえ未だ導体サイズは 大きいので，フレキシブル型ケーブルは寸法的に困㘗 である。

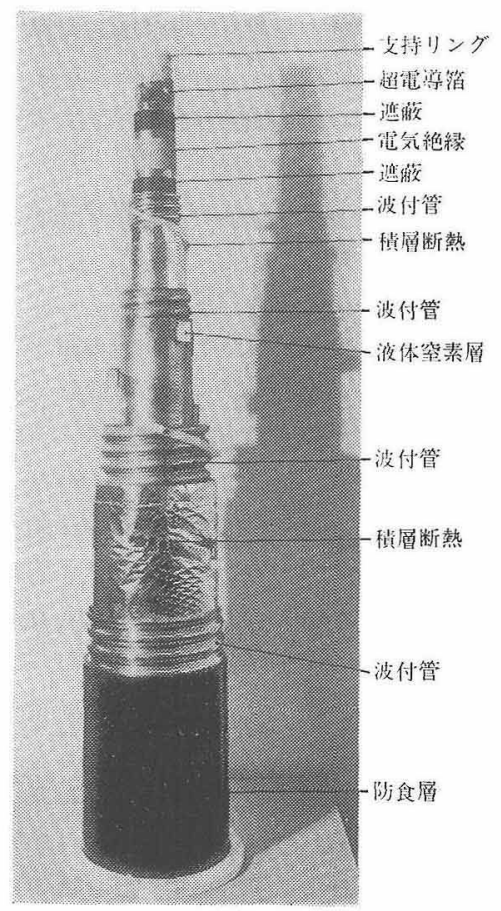

図 3 AEG 社の超電導ケーブル断面図 


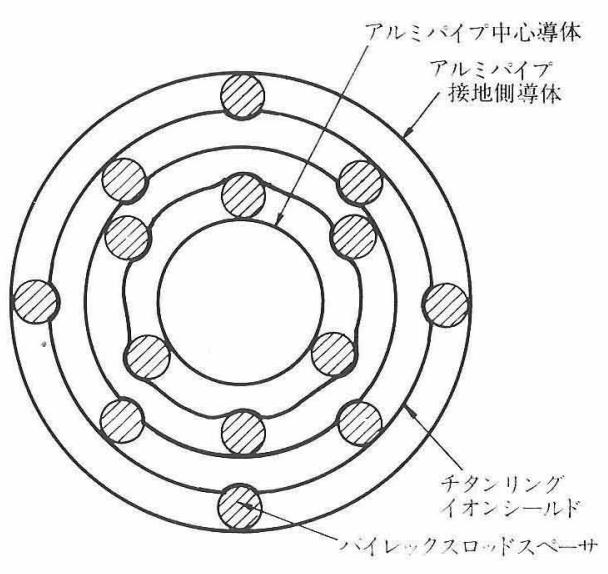

図 4 UGC 社の抵抗性低温々ーブル断面図

\section{4. 断 熱}

低温ケーブルの断熱設計においていくつかの重要な 要素がある。第 1 はその運転温度であり,この点につ いては一般の低温容器とかわらない。第 2 の要素は許 容温度上昇, 許容王力降下と関連寸る最大泠却区間展 である。これは低温ケーブル・システムの製造，運転 コストに大きく影響する。第 3 の要素はその流入熱と ケーブル内部発熱とのバランスである。内部発熱より 流入熱を極端に小さくしても意味はない。第 4 は断熱 管製造コスト，第 5 はメインテナンスに関する考慮で ある。電力ケーブルの信頼性は極めて重大な問題であ り，断熱部の損傷，保守点検にともなう停電は絶対に 避けなければならない。これらの要素它考慮して断熱 方式を選択する必要がある。

\section{1 断熱方式}

断熱方式を大別すると真空杂利用するものとしない ものに分けられる。真空を利用する方式には積層真空 断熱, 高真空断熱, 粉末真空断熱があり，一般に優れ た断熱性能圭有する。積層真空断熱は Al 箔, Al 蒸 着ポリエステルなどの輻射板をグラスウール，プラス チックネットなどのスペーサを介して多層積層し， $10^{-5}$ torr 以下の真空に保持するものであり，最も優 れた断熱方式である。したがって，低温ケーブル用と しても盛んに研究されているが，その際荷重支持法が 問題となる。積層体で支持すると面圧が大きくなり断 熱特性が悪くなり，また荷重支持用スペーサを別にも うけるとそれをとおして流入熱が増す。この他，真空 を利用するどの断熱方法についても辰尺真空排気と真 空保持が大きな問題であり，新しい考案が必要である

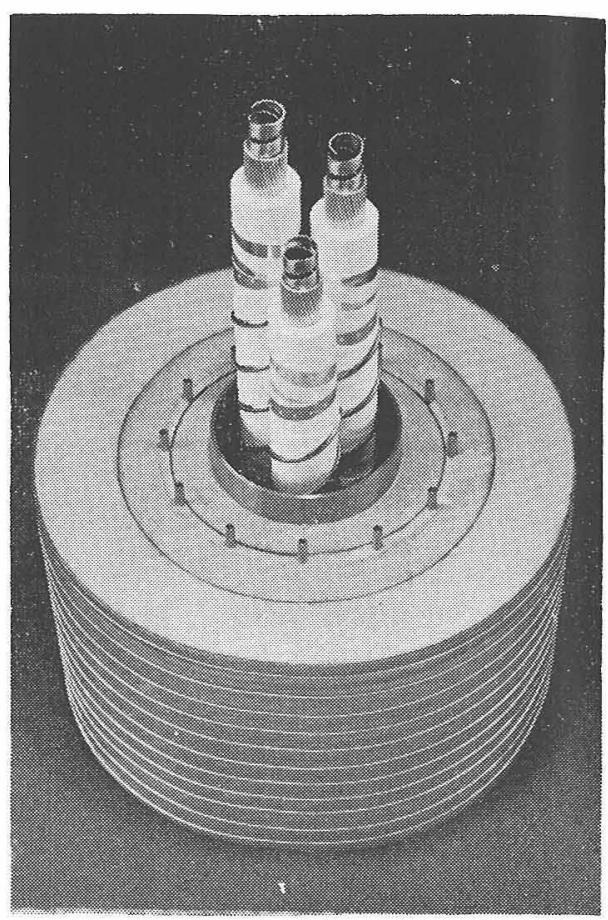

図 5 日立電線の液体䆟素泠却低温ケーブル 断面図

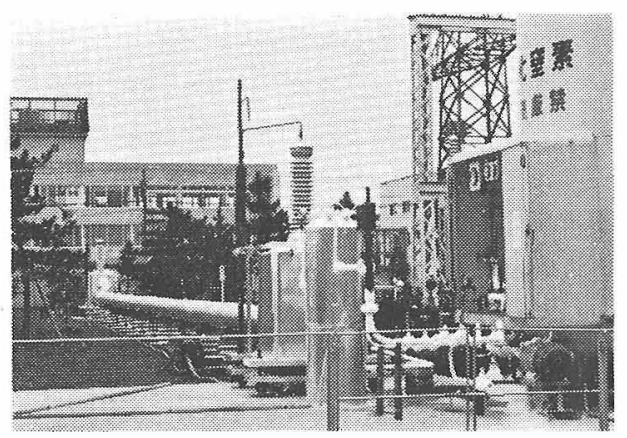

図 6 試 験 状 涊

5。真空党利用しない断熱には発泡断驇，粉末断熱が あり，一般にその断熱性能はよくない。しかし，真空 排気にともなら問題がなく，信頼性に富む。

\section{2 低温ケーブルへの応用}

実験規模ではあるが低温ケーブルの断熱方式につい ていくつかの例をあげる。

液体空素冷却ケーブル 液体奚素冷却抵抗性ケーブ ルでは導体発熱は大きく, $500 \mathrm{kV}, 6,000 \mathrm{~A}$ 級のケ一 ブルではその発熱は $200 \mathrm{w} / \mathrm{m}$ 程度になる。発泡断熱 でも $50 \mathrm{w} / \mathrm{m}$ 程度の断熱は可能であるから十分使用に 


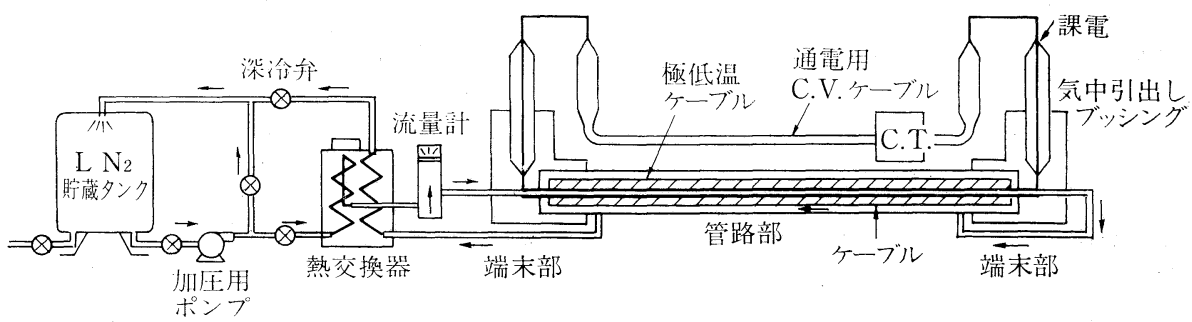

図 7 、試験線路の冷媒循環系統図（矢印は液体窒素の流れの方向を示す）

耐え，真空を利用しないことによる 信頼性を考慮すれば液体窒素冷却ケ 一ブルに最適といえよう。発泡ポリ ウレタン断熱を施した日立電線にお ける $66 \mathrm{kV}, 1,000 \mathrm{~A}$ 級液体窒素冷 却ケーブルについて, 冷媒の循環経 路にしたがい各部所の温度上昇を図 8 にしめす ${ }^{10)}$ 。管路流入熱による温 度上昇は $1,000 \mathrm{~A}$ 通電時 1 相分の導 体発熱より小さく, 発泡ポリウレタ ン断熱で問題ないことがわかる。

超電導ケーブル 超電導ケーブル の断熱は液体窒素温度程度の中間温 度で熱を汲み出し, 常温一液体窒素 温度, 液体窒素温度一液体へリウム 温度と 2 段の断熱をおこならのが一 般的である。超電導ゲーブルは発生熱が少なく，また 泠却効率も悪いので, できるだけよい断熱方式をもち いる。したがって, 高真空断熱, 積層真空断熱に限ら れる。

リジッド管路の場合，8２0m 程度の管路を接続す るが, 工場でユニットごとに真空封じ切りにする方法, 接続後長尺真空排気して封じ切る方法, 接続後運転中 も常時真空排気する方式が考光られる。UCC 社では ユニットごとの真空封じ切りを考え， $10^{-7}$ torr に工 場で排気し内部に挿入した活性炭によりへリウム微少 リークを吸着させ，60年間高真空を保障できると考え ている。UCC 社の断熱構成は $\mathrm{Al}$ 箔とグラスウール による積層断熱であり，この中に銅テープ 6 枚を挿入 し帰路ガスにより中間温度に固定することにより, 積 層断熱の $1.5 \%$ 亿流入熱を拉さえている。

フレキシブル・ケーブルの管路は二つの大きな問題 がある。一つは断熱構造が曲げに耐えられる必要があ ること,もら一つは真空コンダクタンスがきわめて小

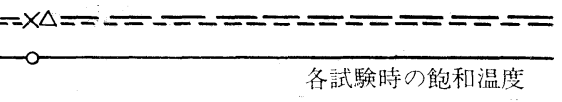

$1,000^{\mathrm{A}}$

$500^{\mathrm{A}}$

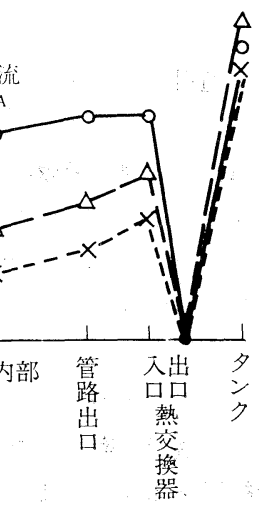

図 8 試験線路各部の泠媒の温度上昇

(図 7 冷媒循環系統図参照)

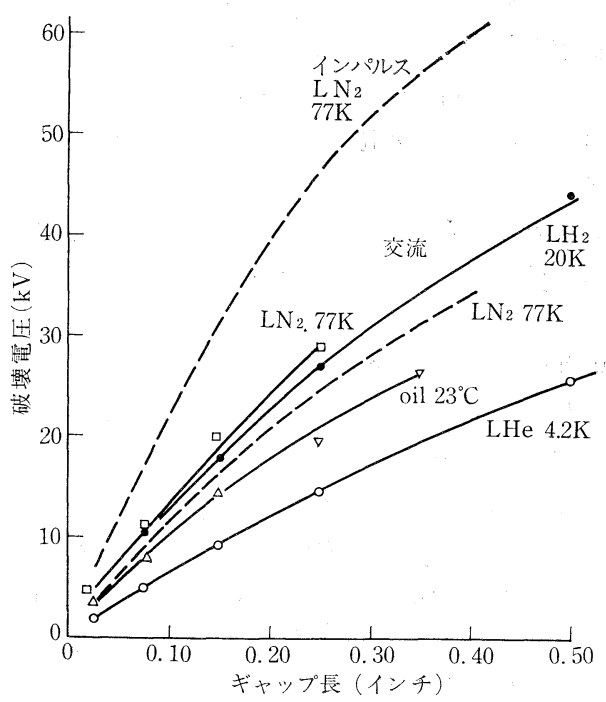

図 9 低温液体の破壊電圧

（破線は筆者の測定結果） 
さいことである。曲げの問題は高真空断熱ではスペー サをへリカルに巻くことにより, 積層断熱ではテープ 状の輻射板, スペーサを横巻きすることにより解決で きるが, その断熱性能は悪くなる。真空排気の問題に ついては, AEG 社のフレキシブル・ケーブル (図 3) では液体窒素層に吸着郕をつけ，これを炭酸ガスでパ ージした後 1 torr 程度に排気し, 液体窒素をながし 凍結する方法を検討している ${ }^{19)}$ 。

\section{5. 電気 絶 縁}

一般に極低温では材料固有の絶縁特性，誘電特性は 良好となる。しかし機械的特性の低下や熱収縮，熱応 力が大きいことを考えると実際の低温ケーブルの電気 絶縁は必ずしも楽観的ではない。ここでは低温ケーブ ルに適用できそうな，または実際に検討されている絶 縁方法を中心に気体, 液体, 固体, 真空およびこれら を組合せた複合絶縁に分け紹介する。なお，低温ケ一 ブル用電気絶縁としては少なくとも油浸紙なみの絶縁 性能（交流 $50 \mathrm{kV} / \mathrm{mm}$ ，インパルス $105 \mathrm{kV} / \mathrm{mm}$ ) と 冷却効率の点から $0.01 \%$ 以下の誘電正接のものが必 要であろう。

\section{1 気体絶縁}

液体窒素温度以下では気体は大部分液化するので, 絶縁用気体としては $\mathrm{He}, \mathrm{H}_{2}$ に限られる。これらの低 温に扮ける誘電正接は $10^{-7} \%$ ときわめて小さい。破 壊電圧に関しては低温でも Paschen's law*が成り立 ち, 密度増加分だけ破壊電圧は上昇する。超臨界 $\mathrm{He}$ は破壊電圧が高く,たとえば $1 \mathrm{~mm}$ ギャップに対して 5 atg に加圧された $\mathrm{H}_{2}$ ガスや液体 $\mathrm{N}_{2}$ と同程度（約 $50 \mathrm{kV} / \mathrm{mm})$ の破壊電圧を示し, 常温の油よりも高く なる ${ }^{20)}$ 。

このため数万V以下のケーブルについては超臨界 $\mathrm{He}$ ガス絶縁や超臨界 He ガス含浸複合絶縁が使用できよ ら。しかし, ギャップ 長が長くなると破壊電圧は Paschen's law から外れ飽和の傾向にあるので, 超高 電圧ケーブルとしては問題が残されている。

\section{2 液体絶縁}

液体絶縁については大気圧, 沸騰状態に扔いて研究 されており，その絶縁特性を図 9 亿しめす ${ }^{21}$ 。液体 $\mathrm{He}$ はやや低いが, 液体 $\mathrm{H}_{2}$, 液体 $\mathrm{N}_{2}$ は絶縁油以上

*)気体の絶縁破壊に関しては一般に“破壊電圧は気 圧とギャップ長の積により一義的に決まる”とい

うPaschen's law が成立っている。
の特性をもっている。液体 $\mathrm{N}_{2}$ 亿関する我々の測定で は, 破壊電圧は交流ではギャップ長の 0.8 乗に, イン パルスでは 0.5 乗に比例する。また, 同一液体にくり 返し課電し劣化をみたが, その破壊電圧は絶縁油に認 められるような回数による低下はみられなかった。低 温液体の誘電正接低電界では $0.001 \%$ 以下と小さい が, 電界が高くなると急激に増加し $0.1 \%$ 以上にもな る。

最近, 絶縁破壊の機構や誘電正接の増加の原因の追 求とともに低温液体中のコロナ放電に関する研究も活 発におこなわれている。しかし，ケーブルに適用する 場合には気体絶縁や真空絶縁と同様にスペーサを必要 とし, 絶縁性能の良否はスペー步部の沿面閃絡性能に 支配されるが，これらのデータはあまり集積されてい ない。

\section{3 固体絶縁}

温度低下とともに有極性材料の比誘電率は減少し, 無極性材料のそれは密度増加分だけ増加する。誘電正 接はある温度や周波数でピークをしめしながら次第に 減少する。市販の $100 \sim 200 \mu$ 厚のプラスチック・シ 一トの誘電正接を図10にしめす ${ }^{23)}$ 。

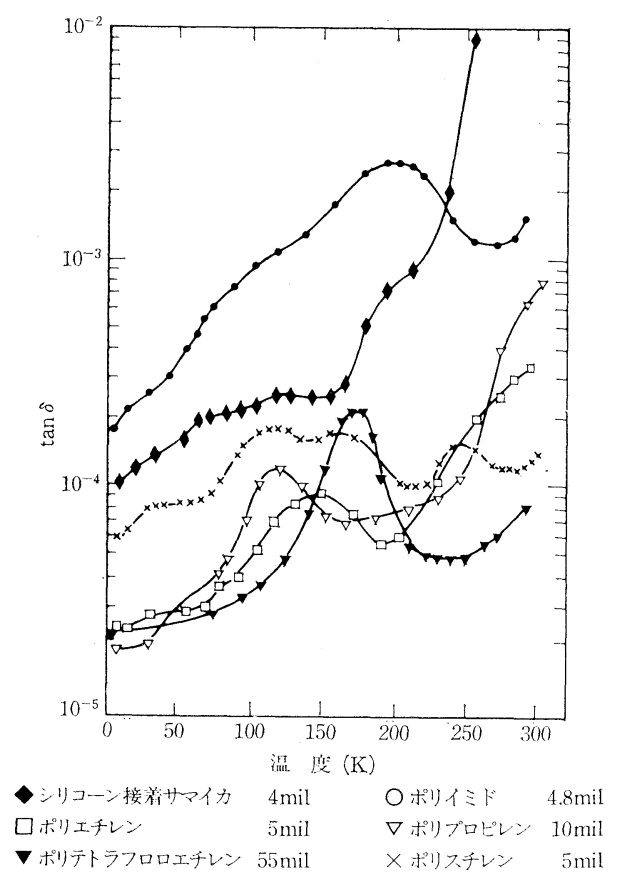

図10 プラスチックシートの誘電正 接一温度特性 (at $75 \mathrm{~Hz}$ ) 
表 1 各種フィルムの破壊電圧 $(30 \mathrm{~mm} \phi$ 球一平板電極)

\begin{tabular}{|c|c|c|c|c|c|c|c|c|c|c|}
\hline \multirow[b]{2}{*}{$\begin{array}{l}\text { 試 料 名 } \\
\text { 厚 さ }(\mu \mathrm{m})\end{array}$} & \multicolumn{5}{|c|}{ 交流破壊電圧（波高 MV/cm） } & \multicolumn{5}{|c|}{ 直流破壊電圧 $\mathrm{MV} / \mathrm{cm}$} \\
\hline & $\begin{array}{l}\text { 空 気 } \\
293^{\circ} \mathrm{K}\end{array}$ & $\begin{array}{l}\mathrm{N}_{2} \\
\text { 液 } \\
77^{\circ} \text { 体 }\end{array}$ & $\begin{array}{c}\mathrm{N}_{2} \\
\text { ガ}^{\circ} \text { 不 } \\
77^{\circ} \mathrm{K}\end{array}$ & \begin{tabular}{|c|}
$|c|$ \\
液 \\
$4.2^{\circ}$ 体 \\
K
\end{tabular} & \begin{tabular}{|cc|}
\multicolumn{2}{|c}{$\mathrm{He}$} \\
ガ \\
$4.2^{\circ} \mathrm{K}$
\end{tabular} & $\begin{array}{l}\text { 真 空 } \\
10^{\circ} \mathrm{K}\end{array}$ & $\begin{array}{c}\mathrm{N}_{2} \\
\text { 液 体 } \\
77^{\circ} \mathrm{K}\end{array}$ & $\begin{array}{c}\mathrm{N}_{2} \\
\text { ガ } \\
77^{\circ} \mathrm{K}\end{array}$ & $\begin{array}{c}\mathrm{He} \\
\text { 液 体 } \\
4.2^{\circ} \mathrm{K}\end{array}$ & $\begin{array}{c}\mathrm{He} \\
\text { ガ } \\
4.2^{\circ} \mathrm{K}\end{array}$ \\
\hline ポリエステル & 1.19 & 1.71 & 0.99 & 1. 20 & 0.85 & 2.12 & 2.1 & 1.6 & 2.1 & 1.5 \\
\hline P T F E & 1.13 & 1.41 & 0.97 & 1.34 & 0.99 & 3.02 & 2.0 & 1.7 & 2.3 & 1.4 \\
\hline ポリエチレン & 1.27 & 1.37 & 1.12 & 1.44 & 1.145 & 25.4 & 2.1 & 1.7 & 2.2 & 1.6 \\
\hline ナイロン & 1.02 & 1.55 & 1.06 & 0.92 & 0.70 & 1. 45 & 1.8 & 1.2 & 1.8 & 1.1 \\
\hline $\mathrm{PVC}$ & 1. 10 & 1.27 & 0.99 & 1.11 & 0.73 & 2.0 & 2 & 1.8 & 2.4 & 1.6 \\
\hline ポリイミドフィルム & 1.12 & 1.09 & 0.97 & 1.05 & 0.75 & 1.82 & 1 & - & 2 & 1.5 \\
\hline クラフト紙 & 1.40 & 1.98 & 1.27 & 1.63 & 1. 27 & 3.17 & 2.4 & 1.8 & 2.6 & 1.9 \\
\hline
\end{tabular}

絶縁性能は表 1 にしめすように常温より上昇する傾 向にある ${ }^{24)}$ 。しかし, 表 1 の值は真空中がもつとも高 く, 気体中よりも液体中, $\mathrm{He}$ 中よりも $\mathrm{N}_{2}$ 中と媒質 の絶縁性能に依存しており，かならずしも材料自身の 温度特性とはいいがたい。

プラスチックは常温ではコロナ放電をともなら課電 を長時間続けると水分や酸素のため劣化したり，トラ ッキング (放電痕跡) を生ずるが，低温では水分，酸 素の固化によりこれらの損傷は少なくなると予想され る。しかし，絶縁厚が厚くなるとクラック，熱收縮の 問題があり，超高電圧絶縁を固体だけでおこなうには 何らかの詨策が必要である。

\section{4 複合絶縁}

固体もシート状ではクラックが入りにくいことか ら，これを積層し，その隙間に良好な絶縁特性をもつ 気体, 液体を入れた複合絶縁は，OF ケーブルの油浸 紙絶縁同様積層による絶縁特性の向上も期待できる。 また，テープ状にし横巻きすることによりフレキシブ ルになる。

液体窒素含浸複合絶縁について我々がモデルケーブ ル試料をつかい検討したこと芫例にとり述べる ${ }^{25) 。 モ ~}$ デルケーブルは $16 \mathrm{~mm} \phi, 450 \mathrm{~mm}$ 長の銅パイプ上に 幅 $20 \sim 30 \mathrm{~mm}$ の絶縁テープを $1 \mathrm{~mm}$ のすきまをあけ 横巻きされたもので, 図11にしめすように加圧され沸 点以下に冷却された液体窒素中に浸積された絶縁テー プは電気特性だけではなく, クラックの入りにくさ, 液体窒素の含浸性などの点も検討し選択される必要が ある。各種材料を試験した結果, ポリエチレン合成紙 (Dupont 製 Tyvek) がもっとも優れていた。この紙 はポリエチレンの長い繊維を熱と圧力で自己融着した ものでポリエチレン $100 \%$ の合成紙である。この試料 の測定結果注次のとおりである。

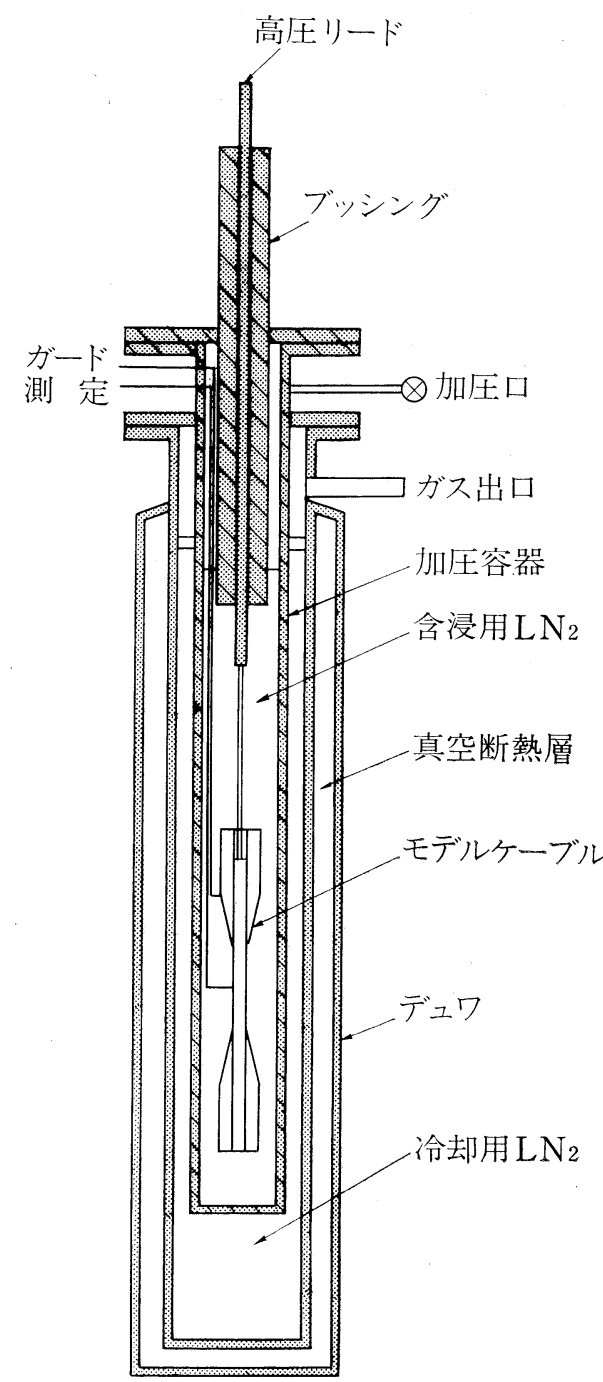

図11 試験用クライオスタットとモデル ケーブルセット状況 
表 2 液体窒素含浸ポリエチレン合成紙絶縁の インパルスくり返し課電試験結果

\begin{tabular}{|c|c|rll|}
\hline 印加電圧 & $\begin{array}{l}\text { インバルスくり返し課電 } \\
\text { 結果 }\end{array}$ & \multicolumn{2}{|l|}{$\begin{array}{l}\text { インバスくり返し課電後 } \\
\text { の流破壊電庄 }\end{array}$} \\
\hline$+80 \mathrm{kV}$ & 3 試料とも 1,000 回 OK & 55.0 & 55.0 & $60.0 \mathrm{kV}$ \\
\hline$-80 \mathrm{kV}$ & $\prime \prime$ & 58.5 & 56.0 & 57.0 \\
\hline$+90 \mathrm{kV}$ & $\prime \prime$ & 59.5 & 56.0 & 55.5 \\
\hline$-90 \mathrm{kV}$ & $\begin{array}{l}2 \text { 試料は 1,000 回 OK } \\
1 \text { 試料は1 回目破壊 }\end{array}$ & 58.0 & 56.0 & \\
\hline
\end{tabular}

真空は電気的にも熱的にも本質的 に絶縁性をもっている。しかし，こ れを電気絶縁に使うには断熱以上に いくつかの問題がある。一つはスペ 一サの沿面破壞の問題であり, この 他, 長尺真空排気および保持, 電極 材料, コンディショニング, 残留ガ ス, さらに低温ケーブルに適用する 際には低温面にトラップされた物質 の影響などの問題がある。しかし，

低温冷媒によるクライオポンプの効果を上手に利用す ることにより高電圧絶縁も可能になるかもしれない。

\section{6. おわりに}

低温ケーブルの開発状況々問題点, とくに断熱方式, 絶縁方式について述べてきた。ここで述べなかった大 きな問題として冷却機などの冷却システムがある。20 〜30年を保障しなければならない低温ケーブルの開発 は低温技術の信頼性が重要な要素である。低温ケーブ ル開発にたずさわるものの一人として, 低温工学に関 係する諸氏の御指導, 御協力を打願いする次第である。

\section{参 考 文 献}

これに対して, 前述した $66 \mathrm{kV}$ 級ケーブル（絶縁 厚 $7.75 \mathrm{~mm}$ ) の電気特性は

$\begin{array}{ll}\text { 交流破壊電压 } & 250 \mathrm{kV}(43 \mathrm{kV} / \mathrm{mm}) \\ \text { インパルス破壊電圧 } & 526 \mathrm{kV}(89 \mathrm{kV} / \mathrm{mm}) \\ \text { 誘電正接 } & 0.001 \%(40 \mathrm{kV} \text { にて })\end{array}$
であり, 破壊電界の低下は小さく, 超高電圧絶縁も可 能と思わ机る。

電気絶縁の信頼性を確認する方法として交流長時間 課電試験とインパルスくり返し課電試験がある。ポリ エチレン合成紙の結果を図 12 ，表 2 にしすす。図12か ら破壊電圧 $(\mathrm{V})$ と課電時間 $(\mathrm{t})$ の関係を求めると $\mathrm{V}=47.4 \mathrm{t}^{-0.046}$ となり, $20 \mathrm{kV} / \mathrm{mm}$ 以下の電界では 30 年間の使用に十分耐えることがわかる。表 2 からくり 返し課電の影響はないことがわかる26)。

この他, 複合絶縁として超臨界へリウム含浸絶縁, 低融点液体含浸絶縁が検討されている。前者は超電導 ケーブルの絶縁として有望であり，後者は液体窒素温 度一常温間での使用を考えている。低融点液体として は石油エーテル，フレオン $\mathrm{R}-12$ などがあげられ，基 礎的な電気試験の後 $154 \mathrm{kV}$ 級の常温と液体窒素温度 を結ぶブッシングが試作されている27)。

\section{5 真空絶縁}

1) R. Mcfee : Elect. Eng. (Feb. 1962) 122

2) W.F. Gauster et al : World Power Conference (1964)

3) R. L. Garwin et al : Proc. IEEE (Apr. 1967) 538

4) K. J. R.Wilkinson : Proc. IEE (Sept. 1966) 1509

5) E. C. Rogers et al : Conf. Low Temp. \& Elect. Power (1969) 209

6) S.H.Minnich et al : IEEE Winter Power Meeting $70 \mathrm{cp} 169$ (Jan. 1970)

7) 電力中研 : 新送電方式検討会中間報告 (May 1963)

8) 電力中研 : 極低温送電 (Mar. 1973)

9) 野口他：昭48電学全大 No. 143

10) 深沢他：日立評論 54 No. 4 (Apr. 1972) 80

11) 岩田他: 古河電工時報 No. 53 (Dec. 1972) 37

12) 久保他：藤倉電線技報 No. 49 (Nov. 1973) 1

13) L.K. Eigenbrod et al : IEEE, Trans. on PAS Vol. PAS 89, No. 8 (Nov. 1970) 1995

14) V.G. Bogner et al : ETZ-A Bd. 94 H. 5 (1973) 740

15) M. Aupoix et al : Conf. Low Temp. \& Elect. Power (1969)

16) V. H. Voigt : ETZ-A Bd. 94 H. 5 (1973) 256 
17) P.Graneau et al : IEEE, Trans. on EI Vol. El-6 No. 1 (Mar. 1971) 39

18) M. J. Jefferies et al : IEEE PES Conf. on UT 72 CHO 608-O-PWR (May 1972)

19) G. Bogner : CEC Conf. (Aug. 1973)

20) R. J. Meats : Proc. IEE Vol. 119 No. 6 (June 1972) 760

21) K. N. Mathes : IEEE Trans. on EI Vol. E I-2 No. 1 (Apr. 1964) 24

22) 堀井他: 電学放電研究会資料 ED-72-23 (Oct.
1972)

23) R. N. Allan et al : Proc. IEE Vol. 115 No. 3 (Mar. 1968) 432

24) J. Bobo et al : Rev. Gen. de L. Elect. Vol. 77 (June 1968) 605

25) 深沢他：日立評論 56 No.4 (Apr.1974) 49

26) 深沢他：第12回低温工学研究発表会予稿集 A29 (Nov. 1973)

27) 酒井他：電学絶縁材料研究会 IM-73-17 (May 1973)

\section{国際会議案内}

\section{Symposium-Course \\ "Hydrogen Energy Fundamentals"}

主催: Clean Energy Research Institute

School of Engineering \& Environmental

Design

University of Miami

P. O. Box 248294

Coral Gables, Florida 33124

後援: The School of Continuing Studies

University of Miami, Coral Gables, Florida

日時：1975年 3 月 3 日 5 日

場所 : University of Miami, Florida

今年度マイアミで行われた水素の国際会議の成功に 引き続き，水素エネルギーのシンポジウムが計画され ている。Formal 及び informal な講演と発表及び panel discussion を含む 4 つたッションが每日用 意されている。このプログラムは，入門者には基礎的
理解を, specialist に対しては水素エネルギーサイク ル全体にわたる広汎な理解を提供し得るものである。 参加費 : 200 250ドル (Proceeding を含む) 連絡先: Hydrogen Energy Symposium-Course University of Miami School of Continuing Studies P. O. Box 248005

Coral Gables, Florida 33124

U.S. A

（前号に追加） 1974年

11月

13-14日 Gastech 74 (LNG/LPG Marine Technology Congress)

Amsterdam, The Netherlands

B. Singleton, Europort Exhibitions Ltd, 6-7 New Bridge St., London EC 4, UK 